\title{
E-waste challenges in Cape Town: Opportunity for the green economy?
}

\begin{abstract}
E-waste research on South Africa cities is modest compared to the much larger research output on other African cities (e.g., Accra, Ghana, and Lagos, Nigeria). Synthesizing gray reports, academic literature, and findings from 25 interviews with key Cape Town stakeholders (from informal and formal firms and industry, civil society, and governmental organizations), this paper assesses the current e-waste landscape in Cape Town, bifurcated between numerous informal individuals/firms and a handful of large formal operators. E-waste activities focus on collection (with little value added), dismantling, preprocessing, and refurbishment without final processing, the latter being performed in Johannesburg and overseas. After a decade of e-waste deliberation, government, businesses, industries, consultants, and civil society organizations are coalescing around approaching e-waste as a strategic green economic opportunity, a tilt coinciding with the designation of Africa's first designated green special economic zone at Atlantis. The green economy tilt, however, is by no means guaranteed: deficiencies in data, e-waste infrastructure, capacity building, and major differences of opinion about the role of informal operators persist.
\end{abstract}

Keywords: e-waste, Cape Town, informal economies, green transition

\section{Introduction}

Globally, the amount of e-waste generated in 2017 was 44.7 million metric tons, an amount equivalent to 4,500 Eiffel Towers (Baldé et al., 2017: 4). E-waste presently is a US\$52 billion global industry of recycling and processing of electronic devices and of re-exporting retrievable metals (Baldé et al., 2015: 17). The growth of the global electronics market with its industry norm of planned obsolescence has spearheaded the expansion of e-waste (Daum et al., 2017). E-waste in Africa is further compounded by an uptake in second-hand and refurbished electronics (Grant, 2015; Grant \& Oteng-Ababio, 2016). Products in the region's secondary electronics market have shorter life spans and enter the domestic waste stream sooner rather than later (Grant \& Oteng-Ababio, 2013; Baldé et al., 2017).

In South Africa, e-waste is growing at three-times the rate of solid waste (Lydall et al., 2017). In the country's Western Cape Province, e-waste accounts for approximately $8 \%$ of total waste (GreenCape, 2018: 17), and 1\%-2\% of materials disposed of in Cape Town's landfills consist of e-waste (ERA, 2018: 33). Within national policy and media circles, e-waste is portrayed as providing both threats and opportunities. The former is mostly expressed as a source of environmental contamination (Finlay \& Liechti, 2008; Lawhon, 2013; Ledwaba \& Sosibo, 2017) arising from improper treatment of e-waste where significant quantities of less valuable fractions are routinely discarded (e.g., plastics, glass), and non-negligible amounts of potentially toxic substances (e.g., cadmium, mercury, lead, brominated flame retardants, or polychlorinated biphenyls [PCBs]) pose environmental health risks from inhalation of toxic fumes as well as from accumulations of chemicals in soil, water, and food, particularly in the vicinities of unregulated landfills (Machete, 2017). Despite the national government's 
attempts to regulate landfills (2013-2016 at a cost of US\$2.44 million), the extent of compliance remains unknown and some e-waste is dumped indiscriminately (Godfrey \& Oelofse, 2017: 4).

As far as its emerging opportunities (the focus of this paper), if e-waste is treated comprehensively (as opposed to an isolated problem) and properly managed with the positive integration of informal economy workers, the sector can address the triple challenges of job creation, poverty, and inequality as well as promote environmental sustainability, thereby aligning in accordance with the South African government's commitment to protect the rights of all its citizens in an environment that is not harmful to health and well-being and with the United Nations' sustainable development goals (SDGs) (DST, 2013). The national government aims to increase the waste and secondary resources sector from $0.51 \%$ to $1.0 \%$ $1.5 \%$ of GDP (DST, 2013). The development of more sophisticated processing offers potential for recovery of valuable recyclable materials such as gold and silver.

Waste is designated as a strategic policy area of the Western Cape Government's "green is smart strategy" (Western Cape Government, 2013), and opportunities exist to transform ewaste along all parts of the chain (e.g., collection, dismantling, pre-processing, final processing). Greening the South Africa economy is hotly debated (Borel-Saldin \& Turok, 2013; Swilling et., al. 2016; Mohamed, 2019) in terms of its definition, scope, opportunities and challenges. A wide range of green economy discourses are employed by different actornetworks constituencies (Mohamed, 2019). In South Africa, tensions and contradictions exist between technocentric environmental managerialism, state-led or market-driven (Olefose et. al. 2006) and citizen-led-focused green transformation with an emphasis on inclusion and/or more radical focus on post-growth, environmental/social justice and the application of nonmonetary indices of the valuation of nature (Mohamed, 2019). South Africa's greening of the economy debate is far from resolved. While a green economy vision is frequently mentioned in official reports, there is a paucity of research connecting the informal economy and the green economy (Mohamed 2019; Smit \& Musango, 2015a; 2015b). This paper focuses on exploring opportunities for the e-waste economy within green thinking and also reflects on some gaps and potential openings. The designation of the Atlantis Special Economic Zone (SEZ); $40 \mathrm{~km}$ from Cape Town as Africa's first green-tech economic zone in 2018 is a significant statement of intent and may provide opportunities to harness technologies and to develop a secondary metals facility so that more sophisticated processing can be conducted in the region.

Every country establishes its own list of consumer products considered to be e-waste (Khan, 2016). In South Africa, e-waste covers small and large household appliances; office and information and communications technology (ICT) equipment; consumer electronics and entertainment equipment; lighting; electronics/electronic tools (common to most countries); security and healthcare equipment; and mixed waste electrical and electronic equipment (ERA, 2018). Given the continually expanding scope of computerized products, commodities not traditionally digitized (e.g., running shoes, clothing, fitness bands) now often incorporate an electronic chip so the definition of e-waste needs regular updating (Khan, 2016). Particularly relevant to the Western Cape Province and its ambition to be renewable energy zone, solar panels are likely to be a future e-waste challenge. Further ambiguity exists in defining used products in South Africa. Out of warranty and the expiration of a contract between consumers and manufacturer are less critical concerns for low-income South Africans such that there is a market for factory- or store-rejected goods with packaging/material defects and partial functionality even though the same conditions might 
not be acceptable in a regular market in a developed country. Moreover, South Africa's second-hand goods market is also affected by the inflow of international donations to South African organizations and institutions; such contributions regularly encompass a mix of working/nonworking devices.

E-waste research on South Africa is modest compared to the much larger research output in African cities such as Accra, Ghana (Amankwaa, 2013; Grant \& Oteng-Ababio, 2013, 2016, 2019, Daum et al., 2017) and Lagos, Nigeria (Osibinjo \& Nnorom, 2007; Nnorom \& Osininjo, 2008; Sullivan, 2014). Research on South Africa focuses on the policy terrain and the transition toward a formal system of e-waste management (Lawhon, 2012, 2013), on possibilities for developing a green channel (Anahide, 2007), on green economy possibilities for the informal economy (Smit \& Musango, 2015a, 2015b), and on the potential for applying technological solutions to valuable e-waste fractions (Ledwaba \& Sosibo, 2017). Some case study research has been conducted at industrial sites in Durban (Govender, 2016), BaPhalaborwa (Tshimbana, 2014), and Cape Town (Schluep et al., 2008), but there is a dearth of e-waste research on the macroeconomic geography of metropolitan and provincial districts. At the national level, an important gray literature exists (e.g., Finlay \& Liechti, 2008; Lydall et al., 2017). At the provincial level, GreenCape has published data and provided a general assessment on e-waste in Western Cape Province since 2014 (e.g., (GreenCape, 2016, 2018). In addition, several industry e-waste management plans have been developed (eWasa and ITA PEG, 2014), and two competing plans (SAWEEDA, 2018; ERA, 2018) were under public discussion in July-August 2018.

My paper provides a case study of e-waste in Cape Town and assesses how the sector fits into the overall economic development strategy of Western Cape Province and the City of Cape Town and the national government's waste strategy and emerging e-waste management system. The next section sketches e-waste at the national context because management policies are being enacted at this level. The third section details the case study approach and qualitative methodology. The analysis presents a mapping of the regional circuit of e-waste. The fifth and sixth sections assess the transition to a formal management of e-waste and the development of a green e-waste channel in Western Cape Province. The concluding section provides a set of reflections and argues that if e-waste processing is to be green we must consider the incorporation of informal economy operators to avoid the e-waste discussion from becoming a mere rhetorical tool and narrative of green propaganda and technological progress for a state management system dominated by large formal firms.

\section{The evolving E-waste landscape in South Africa}

There is a sizeable literature on waste in South Africa (Oelofse \& Godfrey, 2008; Godfrey et al., 2017; Godfrey \& Oelofse, 2017), and a modest but growing literature on e-waste. Godfrey \& Oelofse (2017) characterize the country's waste economy as evolving, based on five stages of overlapping development: "the age of landfilling" (a stage South Africa has yet to move beyond); the "emergence of recycling" (marked by the 2001 Polokwane Declaration and a plastic bag use tax after 2003); the flood of regulations: the drive toward Environmental Producer Responsibility (EPR) (reaching a pinnacle in July-August 2018 with public discussions on competing e-waste management plans and differences of opinion about how the government management system should function); and the country is on the brink of a fifth stage of a transition toward a "circular economy." The circular economy makes an important distinction between biological and technological cycles. In the former, biologically 
originating material, such as cotton, feed backs into the system via composting and anaerobic digestion processes. Technological cycles, more applicable to e-waste, recover and restore components, materials, and products through reuse, repair, remanufacture and/or (in the last resort) recycling.

Several organizations have undertaken national assessments of e-waste (Dittke, 2005; Widmer \& Lombard, 2005; Advanced Tropical Environment, 2012; Africa Institute, 2013). eWASA conducted a preliminary baseline assessment of volumes, types, sizes, and roles along the e-waste value chain (Finlay \& Liechti, 2008). DST and the Council for Scientific and Industrial Research compiled the most comprehensive assessment of e-waste based on a survey of South Africa's 100 largest e-waste firms. The resulting report (Lydall et al., 2017) provides a detailed appraisal of the state of technology employed at various stages in the ewaste chain and provides preliminary data on the South African e-waste space economy and the respective roles of cities and provinces through elucidating e-waste collection hinterlands. Graduate theses have studied the green channel (Anahide, 2007), municipality e-waste management (Tshimbana, 2014) and industrial park management (Govender, 2016). E-waste is now receiving multifaceted media coverage and was among the features in Cape Town's 2018 Design Indaba Festival, where e-waste art installations, jewelry, and street art were exhibited (Design Indaba, 2018). Industry assessments of South Africa's cyberthreat show vulnerability due to the poor infrastructure, network gaps, and older equipment but no causal link between digital waste and cybercrimes (e.g., online romance and other scams; African Union Commission and Symantec, 2016).

Unlike Ghana and Nigeria, causal links between e-waste and cybercrime are not established (African Union Commission and Symantec, 2016) even though South Africa ranks near the top of the global list of the most exposed countries to cybercrime. South Africa's cyber-threat is largely a consequence of the poor infrastructure, network gaps, and older equipment (African Union Commission and Symantec, 2016).

A major theme in scholarly research has been the formalization of e-waste management in South Africa and the policy instruments guiding the transition toward sustainability (Lawhon, 2012). Since the late 2000s, policymakers, media, and activists (e.g., South African musician Johnny Clegg, who established New Earth E-Waste Solutions in Johannesburg) highlight the lack of a "proper recycling facility in South Africa" and the loss of potential revenues from ewaste processing of valuable fractions (Jones, 2008: 1). The impetus for a formal industry-led approach is orchestrated via one of the newly established larger e-waste umbrella organizations (e.g., E-waste Recycling Authority (ERA) and South African Waste Electrical and Electronic Enterprise Development Association (SAWEEDA) ${ }^{1}$. Lawhon (2013) surmises that policy has evolved from consultants, academics, and industry representatives collaborating to develop management plans that promote technological solutions to modernize the industry. Indeed, some suggest that management of e-waste should commence from within the public sector as stockpiling e-waste is typical and the government sector may account for $45 \%$ of all e-waste (ERA, 2018).

Approaching e-waste from an informal economy lens, scholars (Smit \& Musango, 2015a, $2015 \mathrm{~b}$ ) and activists call for more attention to the integration of informal waste pickers and

\footnotetext{
${ }^{1}$ ERA steering committee membership was drawn from HP, Dell, DESCO Recyclers, SIMMS Refurbishes, SA Precious Metal, Africa e-Waste and e-Waste Africa, and the SAEWA. The SAWEEDA think tank includes representatives from eWasa, environmental finance businesses, legal organizations, IT producers, industry, and the scientific community).
} 
informal firms sidelined in official plans, which already perform green recycling work with considerable scope for expansion and positive integration. Early stages of recycling (collection, crude dismantling, and sorting) are dominated by informal workers, typically exploited laborers (Finlay \& Liechti, 2008), and their activities affect vulnerable populations living in the vicinity of unregulated sites or backyard workshops. Despite the passing of a variety of environmental and waste-related legislation in South Africa, only formal erecycling facilities offer degrees of worker protection.

\subsection{E-waste in South Africa}

Unlike in other African countries, hundreds of shipping containers are not openly arriving at ports and being channeled into specialized e-waste hubs. Imports of e-waste are modest: approximately $6 \%$ of the total is imported by formal firms from neighboring Southern African countries (Lydall et al., 2017: i), and informal firm imports are unknown. Fifty known producers are active in importing both new and used electronics and many of them engage in local assembly and refurbishment (ERA, 2018:21). Most activities proceed with low-mid-level technology and only a few well-established consolidator companies employ more sophisticated technology (Lydall et al., 2017:x). An important caveat is that while technology is applied to processing in South Africa (e.g., mechanized shredding), it is neither state of the art nor uniform; more advanced processing takes places outside the country (e.g., Belgium, Germany, the Netherlands, and China). Most valuable fractions and more problematic fractions such as batteries are exported for further processing. Since 2017, Johannesburg firms have operated pilots to experiment with more sophisticated processing of metal fractions; for example, SA Precious Metals is engaging in the extraction of precious metals, and Rand Refinery is enhancing its intake of processed e-waste to boost economies of scale in gold extraction.

Most small- and medium-sized firms (SMEs) concentrate in the early stages of the value chain, engaging in collection to processing. Organizing workers in the South African informal waste economy has proven to be particularly challenging. Godfrey and Oelofse (2017: 6) report $92 \%$ of cooperatives fail with waste workers returning to landfills and operating as independent workers. Marginalized collectors have been unable to speak with a uniform or representative voice to negotiate with municipalities and firms along the value chain. Research on collectors reveals internal divisions and hierarchies over the politics of landfill access with network and criminal syndicates also exercising influence (Lambrechts \& Hector, 2016).

Estimates of the total e-waste output in South Africa vary significantly. At the upper end, Snyman et al. (2016: 2) calculate the total value of e-waste at 2 million tons per year. Government and industry associations estimate the national output to be approximately 360,000 tons (GreenCape, 2018), a sum more in line with international organizations' reports (Baldé et al., 2017) of South Africans' annual e-waste generation of $6.2 \mathrm{~kg}$ per inhabitant (the highest in Africa but considerably lower than the US average of $19.4 \mathrm{~kg}$ per person). There is a steady growth rate of IT uptake in South Africa: 52.3 million smartphones; 6 million tablets (Lydall et al. 2017: 70), and 10.5 million computers (DST, 2013) are present in 2019. ${ }^{2}$

Estimates are on shakier ground when calculating the quantity of used devices and equipment in the market and the amount of e-waste in storage. In terms of the market, Finlay and Liechti

\footnotetext{
2 This was calculated employing DEA's (2012) data and projections of 500,000 imports per year and 3-6 years life expectancy.
} 
(2008: 22) calculated imports of 20,000-100,000 used PCs and 720,000 used mobile devices for 2007 and there are no estimates on the quantity of goods in the secondary market. Despite efforts to regulate the second-hand market by the Second-Hand Goods Bill (2008), enforcement is weak, and this market remains largely unregulated. Deloitte (2016: 22) calculate the market share for used mobile handsets is $22 \%$ of the total market. Moreover, many phones remain in storage given South Africans' tendency to hold onto old phones as spares and gifts to family and friends rather than to sell them through a formal or informal market. Imports of affordable new Chinese handsets are chipping away at this market niche except among low-income populations (Deloitte, 2016). Other second-hand markets exhibit more inertia; for example, used domestic appliances. Indeed, Lydall et al. (2017: 70) report an increasing market share for refurbished office IT as firms opt to reduce spending on new equipment following the decline of the South African rand and improvements in refurbishers' lease schemes with enhanced service contracts.

In South Africa waste recycling is low: only 11\% of e-waste is recycled (Lydall et al., 2017). Proposals have been put forward to increase the recycling of e-waste to $20 \%$ within five years (eWASA, 2013). Mouton and Wichers (2016: 464) estimate that " $20 \%$ of e-waste is recycled by formal firms" and "70\% of South Africa's e-waste remains in storage." eWASA (2013: 3) emphasizes that informal operators collect $25 \%$ of the total volume of e-waste recycled.

Lydall et al. (2017) highlight 100 formal firms operating at the apex of the e-waste economy with direct ties to consolidator firms that in turn aggregate the e-waste collected in the informal economy. In general, e-waste recycling is not profitable as a stand-alone business, and many firms regard it as a secondary activity (Lydall et al., 2017). Many small dismantlers combine recycling with more profitable refurbishment. Gauteng-headquartered firms dominate the e-waste economy and handled 55\% of the volume in 2015 (Lydall et al., 2017: x). Many (e.g., Desco, Just PCs, SmartMatta) also maintain branch offices in Cape Town. Most of the valuable fractions processed in Johannesburg are exported for subsequent processing (e.g., PCBs to Europe, Asia, and Canada; phosphors powder to Europe; ferrous and nonferrous metals to Asia (Lydall et al., 2017: x).

\section{Data, methods, and study area}

Most e-waste research in Africa focuses on the salient national hubs, but this research focuses on a largely undocumented secondary site. No national database exists and significant data gaps exists in documenting e-waste. A goal is to document, map, and assess the hitherto unobserved e-waste landscape in Cape Town/Western Province and its various ties to the South Africa e-waste space economy and beyond. 
Table 1: Research phases

\begin{tabular}{|c|c|c|c|c|}
\hline 1. Secondary sources & 2. Interviews & $\#$ & 3. Site reconnaissance & $\#$ \\
\hline eWASA membership list & a. Government & & Firm locations and Atlantis SEZ & 30 \\
\hline SAEWA membership list & Western Cape Government & 2 & & \\
\hline DST (Lydall et al., 2017, & Green Cape & 2 & \multirow{21}{*}{$\begin{array}{l}22 \text { firms verified; } \\
\text { plus } 8 \text { could not be located (of which, } 4 \\
\text { were reported to have relocated but } \\
\text { whereabout could not be determined } \\
\text { and the remainder ceased operating) }\end{array}$} & \\
\hline Annex pp 67) & Westgro & 2 & & \\
\hline \multirow[t]{19}{*}{ Web research } & DTI & 1 & & \\
\hline & DEA & 1 & & \\
\hline & b. Industry organizations & & & \\
\hline & eWasa & 1 & & \\
\hline & SAEWA & 1 & & \\
\hline & c. Formal firms & & & \\
\hline & Cape E-waste & 1 & & \\
\hline & Desco & 1 & & \\
\hline & Just Pcs & 1 & & \\
\hline & Smartmatta & 1 & & \\
\hline & Pcs and Stuff & 1 & & \\
\hline & d. Informal firms & & & \\
\hline & Waste Plan & 1 & & \\
\hline & Bizstorm 5CC & 1 & & \\
\hline & Virgin Earth & 1 & & \\
\hline & Compuscrap & 1 & & \\
\hline & Metrex & 1 & & \\
\hline & e. Informal collectors & & & \\
\hline & Waste Pickers & 5 & & \\
\hline
\end{tabular}

Given the lack of existing data/published research on Cape Town, this research proceeded in three steps. Step 1 involved compiling the listing of e-waste companies and their locations, data were obtained from various professional association lists (see Table 1) and also involved web research to uncover firms that are not listed with industry organizations. Step 2 involved conducting 25 semi-structured interviews with a wide range of stakeholders (5 with government officials, 2 with industry organizations and 5 each with formal firms, informal firms and waste pickers). In terms of the government interviews, some effort was spent prior with industry and professional organizations identifying the key contact or two with the agency engaged with the e-waste portfolio. Given this sector is evolving, a snowball technique was employed to identity key firms and waste collectors that engage in e-waste. Notes were taken during the interviews and they were transcribed later and key representative quotes are presented in the analysis. The analysis section also relies on the gray literature to shed light on the milieu as the interviews revealed that knowledge of the provincial/city ewaste landscape is fragmentary and incomplete especially at the firm level. The response rate was high and only two officials failed to respond to requests for interview and three informal firms declined to participate. Step 1 identified 30 establishments on the master list with 5 or more employees and in step 3 site visits were conducted to verify the addresses and existence of 22 firms that were mapped. Interviewees mentioned itinerant firms/scrap dealers, operating under the radar at the base of the e-waste economy, outside of a premise. However, documenting these actor's largely invisible geographical fields of operations is beyond the scope of this study. Nevertheless, a mapping of fixed e-waste operators was accomplished. 


\section{Results: Western Cape Province and Cape Town as a regional hub}

Many firms participating in the e-waste economy concentrate on collection. The scale of operations varies considerably: from large firms to many micro firms to individual e-waste collectors to opportunistic collectors who occasionally gather e-waste but concentrate on other wastes. At one end of the spectrum are Cape E-Waste Recyclers and Desco. The former organizes a well-developed disposal service for redundant and obsolete equipment to government, medical facilities, educational establishments, and corporations. To augment its service, it regularly holds collection events in partnership with municipalities, churches, and businesses, accepts e-waste from retail stores, and maintains ties to many smaller firms to source sufficient quantities of e-waste to boost economies of scale. Desco operates as a consolidator for the entire Cape (Northern, Western, and Eastern), has ties to large retailers (e.g., Marko, Incredible Connection), and channels approximately $60 \%$ of e-waste collected in the province to Johannesburg for processing (Lydall et al., 2017: ii). At the other end of the continuum, a few micro firms (e.g., Harris Electronic Waste) operate with an explicit empowerment objective to provide jobs for family members, while numerous home-based survivalist enterprises operate from township backyards (e.g., Newtech Recycling).

Unobserved phenomenon such as transitions to regularization by informal firms was difficult to ascertain. It seems that many firms, particularly those on the outskirts of Cape Town, operate beyond the regulatory purview of the municipality and the DEA's requirements of the National Environmental Management Waste Act (NEWMA). Firms are supposed to be registered, get audited, and be in compliance with hazardous waste disposal regulations and international standard certificates (e.g., ISO 9001; ISO 14001; ISO 18001), respectively pertaining to reporting, administering, and operating in compliance with environmental, health and safety, and workplace regulations (GreenCape, interview, June 2018). Interviews with industry organizations report that approximately " $10 \%$ of Cape Town firms are in full compliance (largest firms), some firms partially comply with existing licensing requirements, but most firms are non-compliant" (SAEWA Director, interview, June 2017). Two informal firms emphasize that they are unware if there are requirements, and one of these firm underscored that they "are suspicious of governmental efforts at regularization, fearful of any government management" and worried that this might ruin their livelihoods. As one interviewee put it, "this country has a history of failing promises but only the connected get uplifted out of poverty" (informal firm, interview, June 2018)., wide degrees of noncompliance prevail, ranging from uncontrolled disposal (open burning and dumping) to unsafe manual dismantling and processing (low awareness of risks to safety, health, and the environment in their operating space) to poor and inadequate storage of materials and wastes (especially with nonvaluable waste fractions) to the uncontrolled transportation of materials and quasi-legal trading (unrecorded cash transactions) among firms, particularly at the collection, preprocessing, and refurbishment stages in the value chain. While some of these issues may be heightened in e-waste processing, similar challenges are evident in other sectors of informal economy manufacturing (Grant, 2006; Rogerson, 2006). Based on the interviews conducted in May 2018, it can be condcluded that several firms participate in ewaste collection to assess components and models that can be refurbished. For the most part, these firms are profit-orientated, but there are firms (e.g., Virgin Earth in Somerset West) that operate with the socially responsible objective to provide computers to charitable organizations. Figure 1 shows the locations of 22 Cape Town-based e-waste firms with 5 or more employees, and indicates firms' e-waste portfolios (i.e., collection, pre-processing, refurbishment and final processing). Five national firms maintain regional establishments in the city (indicated by name on Figure 1) but most are informal firms (indicated by number 
and named on the legend). Most firms engage in the beginning stages of the e-waste value chain and firms report that refurbishment is the most profitable activity (Interviews, May 2018).

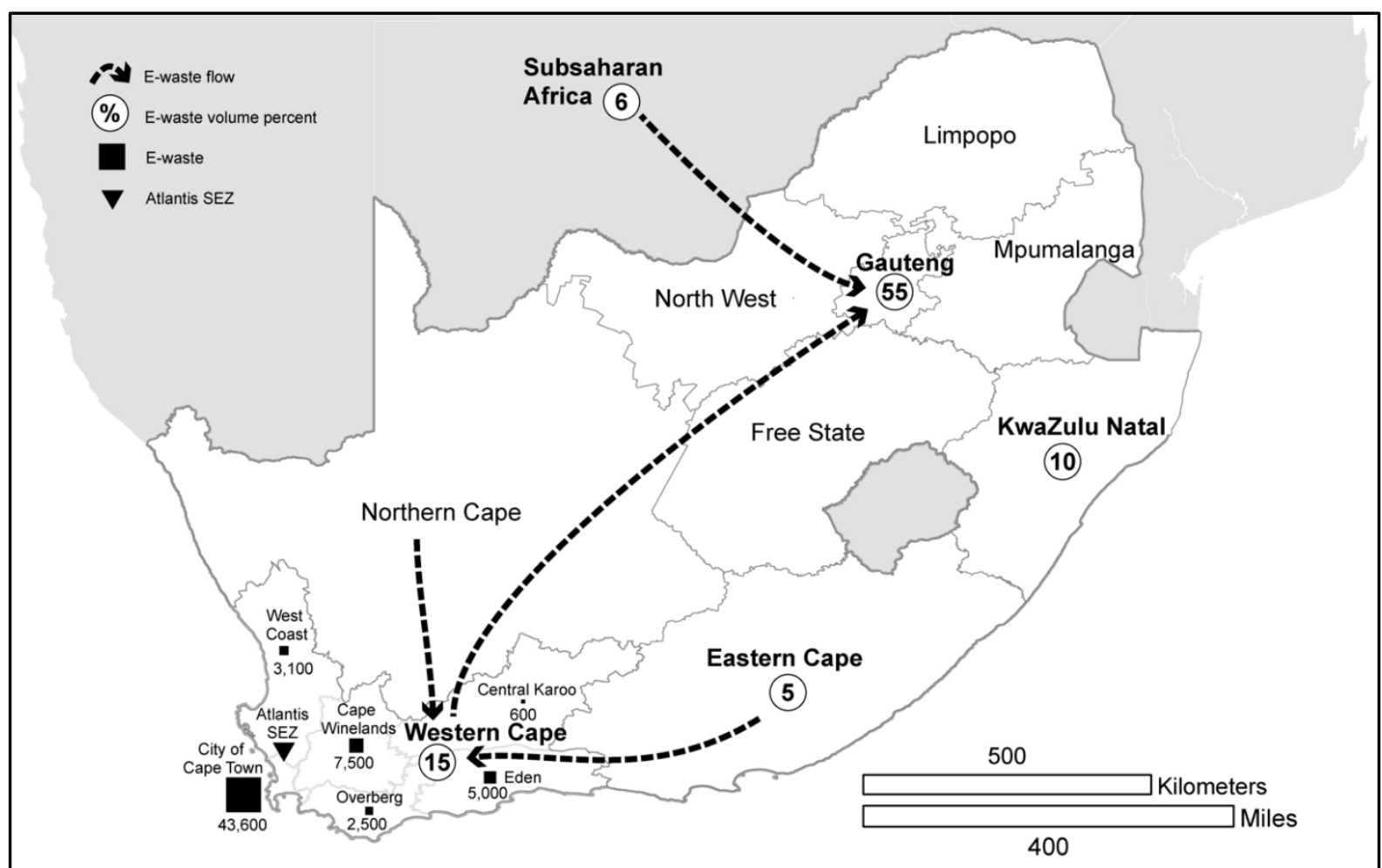

Figure 1: E-waste firms in Cape Town (illustration: Richard Grant).

Interviews with firms were not informative about the volumes of e-waste that companies handled so the secondary literature is more revealing. Business competition was given as the reason that companies did not want to reveal precise figures. GreenCape (2016: 22) notes that the Western Cape Province functions as an important provincial aggregation and sourcing node for approximately 40,000 tons of e-waste. The city of Cape Town generates $70 \%$ of provincial e-waste (Figure 2). Most e-waste firms are located in the northeast of the central business district in the airport's vicinity and in the outer suburbs (e.g., Somerset West and Kommetjie). Western Cape Province is the most important secondary site, handling $15 \%$ of the country's e-waste (see Figure 3). The province serves as a major aggregation node for Western and Northern Cape Provinces. Much of what is consolidated is either dismantled or refurbished, and/or is sent to Gauteng for preprocessing by two large formal companies: Universal Recycling Company handles 3,000 tons per year and Desco processes 5,000 tons annually (Lydall et al., 2017: 46). 


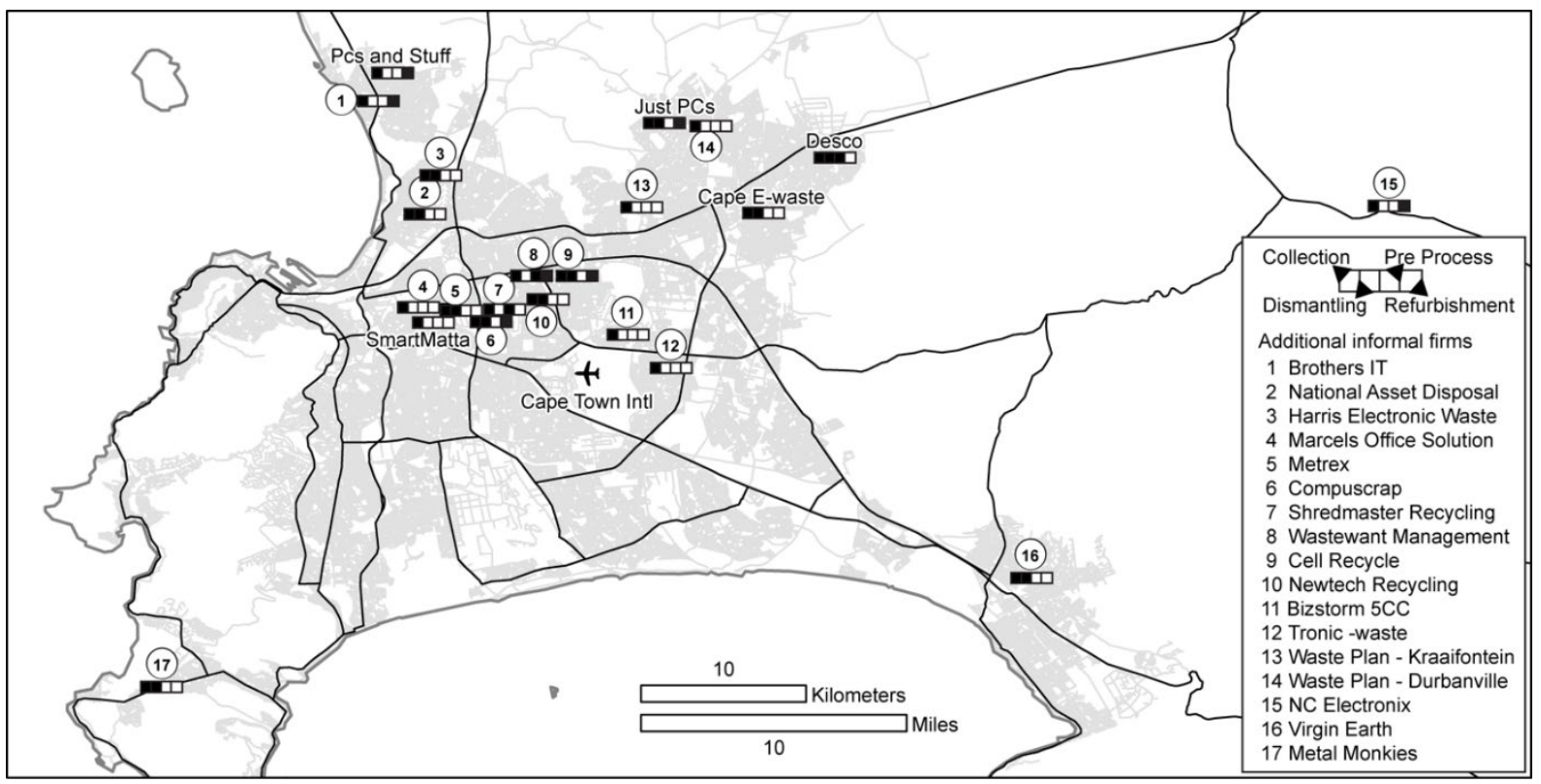

Figure 2: The space-economy of e-waste in Western Province (source: Based on Lydall et al., 2017).

Figure 2 shows that the Southern African region functions as a supplementary source of ewaste, but notice there are no discernible ties between Western Cape Province and Namibia. A Westgro official noted, however, "Cape e-waste firms are exploring extending their geographical reach into the neighboring country in light of the Atlantis designation" (GreenCape, interview, June 2018). Not surprisingly, Gauteng firms are more engaged in cross-border ties due to its proximity to urban centres (e.g., Gaborone and Lusaka) in neighboring countries. Several Cape Town firms export plastic fractions to Asia, but most exporting presently takes place from Johannesburg and Durban (Lydall et al., 2017).

Cape Town's waste pickers report harassment from authorities, community discrimination, personal attacks, and exploitation by profiteering intermediaries across the e-waste value chain, where cash-strapped pickers report little or no bargaining power (Interviews, Waste Pickers, June 2017). Industry associations (e.g., eWasa, SAEWA) have been active in efforts to mainstream informal enterprises by getting them to register as members and involving them in dialogues about management plans, but, as noted, organizing informal e-waste workers has not yielded major successes to date (Godfrey et al., 2016). Collectors report middlemen brokers with direct contacts in municipalities that enable "their men" priority access to public facilities, and a few interviewees alleged that municipal contracts for valuable e-waste fractions "are handed out to their own gang" (without ever undergoing a legal tender process; Waste Picker, interview, June 2017). In the absence of separation at source in South African cities and towns, informal waste pickers are key to accumulating resources (Godfrey \& Oelofse, 2017). Informal waste pickers are very successful in bridging the service component of the South African value chain (collection), paralleling government and private sector buy-back schemes and competing with private firms engaged in collection. Government pilot projects and producers' take-back programs have not yet yielded much business success in competing with the informal sector in door-to-door collection. In addition, formal enterprises that have to bear environmentally sound treatment costs without economics of scale face major profitability challenges.

There are no reliable figures on the number of e-waste collectors in Cape Town. Nationally, approximately 60,000-90,000 informal recyclers/waste pickers/ reclaimers participate in related activities (Godfrey et al., 2016). Schenck et al. (2016) report that pickers tend to be 
exclusively from poor black populations and for the most part are generalists, who collect various wastes (e.g., plastic, metals) and e-waste. ERA contends that 10,000 collectors at some time or another have dealt with e-waste and 2,000 engage e-waste as a core informal business (ERA, 2018: 32). Interviews with informal firms in Cape Town conducted in June 2017 reveal that "small firms each maintain direct contact with approximately 10-20 e-waste pickers engaged in activities around landfills and garden sites" plus "another 5 or so workers/family units that collect e-waste from households and businesses". According to firms interviewed in Cape Town, approximately 200 informal firms in addition to at least 500 waste pickers focus exclusively on e-waste, while thousands of other waste pickers participate part-time and in opportunistic collection (Interviews waste pickers, June 2017, interview informal firm, June 2018). Interviewees report it is mainly men who collect ewaste, but women are well represented at the Stellenbosch landfill (Interview Stellenbosch waste picker, June 2017).

There are consequences for the uncontrolled ways in which e-waste is amassed. Much of ewaste is channeled into landfills, where a good portion of it remains. Low volumes advance through the e-waste chain, system, undermining the business potential of sorting and preprocessing, compared to other African contexts where large volumes of imports are channeled into specialized e-waste hubs. Informal collectors typically sell their e-waste to small scrap dealers who in turn sell to larger scrap metal businesses such as SA Metal, Reclaim, and Universal Recycling. These fully-compliant businesses are registered as buy-in services of e-waste and other metals and operate according to market prices. However, most smaller firms operate informally, not according to market principles, often leading to financial exploitation (ERA, 2018: 32) with some engaging in risky and environmentally unsound behaviors by cable burning to extract copper and/or smashing formerly untampered e-waste to extract the value fractions. In Cape Town, a few locally known applications exist: waste-to-art projects and bumper and pole manufactures are utilizing processed waste. A good example is the work of South African artist Ralph Borland (2018), who creates interactive digital street art with typical handicraft objects and e-waste.

\section{Legal and institutional framework and transition to green economy}

The e-waste policy and management apparatus emerging in South Africa has been strongly influenced by the European experience (Godfrey \& Oelofse, 2017). South Africa's first legal definition of waste was provided by its Environmental Conservation Act (Act 73 of 1989) in the context of managing disposal sites and limiting the negative environmental impacts associated with improperly managed landfills. A 2009 Waste Act obliges manufacturers and South African importers to define an Industrial Waste Management Plan (IWMP) before approval is granted to sell products in the country. DEA has declared that an E-Waste Industry Management Plan (IndWMP) is a necessity.

An initial South African E-Waste Management Plan draft was prepared in 2014 (eWASA \& ITA PEG, 2014), but a wave of criticism and subsequent intransigence resulted in the DEA withdrawing its Section 28 notice in August 2016. Broader stakeholder discussions have since proceeded including wider representation from industry (e.g., South African Domestic Waste Appliance Association (SADA), academia, civil society, and international recycling epistemic communities. Two issues remain especially contentious: (A) the functioning of the Extended Producer Responsibility (EPR) scheme, wherein manufacturers and importers of products should bear a significant degree of responsibility for the environmental impacts of 
their products throughout the products' life cycle (government administered or industry administered and how responsibility might be shared among players in the chain), and (B) how the informal system might be integrated and which informals might be involved.

Earlier public sector and private sector initiatives (e.g., buy-back schemes led by FujitsuSiemens and Nokia and other pilot projects such as secondary metals processing) have been only modestly successful in improving the management of e-waste. The largest vendor in the country, Hewlett Packard (with a 45\% market share of PCs and printers), and various partner organizations ${ }^{3}$ operated a pilot materials recovery recycling facility (2008-2009) in Maitland, Cape Town. This start-up facility combined low-technology and high labor-intensive material dismantling and recovery for preprocessing e-waste and tested the feasibility of an integrated valued-added local e-waste management system designed to maximize the potential of refurbishment, repair, reuse, recycling, waste-to-art and environmentally responsible disposal as a last resort (Schluep et al., 2008). While the pilot registered some successes, particularly in job creation, formidable challenges involving transport cost and adequate storage for ewaste were not overcome, and the site was closed once the funding period ended.

IT vendors have supported the national drive to develop an industry-led solution to e-waste, working in collaboration with eWASA. Retailers (e.g., Woolworth, Pick n Pay, Incredible Connection) and municipalities have participated in collection drives, and although 600 dropoff points and buy-back centres are reportedly in operation throughout the country (Lydall et al., 2017: 12), the number of fully working centres in Cape Town is lower than expected (SAEWA Director, interview, June 2018). Lack of standardization of points/centres (they range from 120-liter wheelie bins to large industrial containers to open spaces) has not helped in building community awareness about this recycling infrastructure. Interviewees report considerable theft of materials, particularly valuable e-waste fractions, from unprotected facilities lacking surveillance (informal firm, interview, June 2018).

The elevation of waste as a priority area in policy is recent. Operation Phakisa (meaning "hurry up" in the Sesotho language) is a novel South African planning intervention approach since 2014 designed to bring stakeholders from government, public/private sectors, academia, and civil society together to consult and formulate solutions to this critical policy area so that they can be delivered in a prioritized, focused effort within five years. Motivated by a realization that "waste management was not sufficiently developed, leading to both missed opportunities and unnecessary environmental impact," a chemical and waste Phakisa conference was convened July 27-August 25, 2017 (Department of Planning, Monitoring and Evaluation, 2017).

Although South Africa has enacted legislation (e.g., National Environmental Management Waste Act 59 from 2008 and the National Environmental Management Act from 1998) to provide basic guidelines on the management of e-waste, adherence is voluntary and unmonitored. Given this considerable gap, the Minister of Water and Environmental Affairs, Edna Molewa, issued a section 28 notice in 2017, calling on industries to submit waste management plans. This notice also indicated that manufacturers will be responsible for managing a product from the beginning to the end of products' life.

\footnotetext{
${ }^{3}$ Swiss organizations such as Swiss Federal Laboratories for Materials Testing and Research, the Global Digital Solidarity Fund, and local Cape Town partners such as EnviroSense and Recycling IT.
} 


\section{Discussion: A green channel in E-waste?}

Western Cape Government's Green Is Smart Roadmap aims for the province to be a pioneer and an early developer of green technologies and diversified green economic activities. This strategy promotes more investment in green-tech firms and fosters deeper linkages among green economy entities. Remarkably "South Africa is the world's fastest growing green economy," with the Western Cape "home to $60 \%$ of the country's green project developers and two thirds of South Africa's green manufacturing" (FTWonline, 2017: 1). At the same time, it is by no means evident if greening the economy will incorporate e-waste and extend its focus beyond energy, transport, human settlements and agriculture and/or transition toward a fully inclusive green economy.

GreenCape and Westrgo officials contend that a green channel can be created that embraces the entire Western Cape e-waste ecosystem. Sustainable recycling operations will contribute to reducing carbon emissions by mining e-waste to recover valuable metals, thereby using only a fraction of the energy required to mine virgin ores in nature (Grant \& Oteng-Ababio, 2016). The pioneering Atlantis SEZ offers the potential to become a catalyst for green tech. DTI views the development of the sustainable management of secondary metals and better local utilization of recovered materials as a potential area for green growth that can be embedded in the Atlantis SEZ (DTI, 2017). Efforts are underway to entice a secondary metals facility to locate in the Atlantis SEZ to link to small collectors and to the Atlantis metal foundry. Western Cape Province aims to benefit from offering value-added services and regional solutions for various aspects of e-waste (repair, refurbishment, processing) and from serving as an exporter to the rest of Africa. Western Cape could also benefit from regional cross-border shipments of e-waste that comply with international and national regulations to increase volumes for local recycling solutions, but it remains to be seen if such an initiative will materialize. It may depend on the successes of embedding green tech as a national development reality. Interviews with policy officials were informative about a consensus to manage e-waste in the context of green growth potential. Major differences of opinion are evident between government and SAEWA about the necessity of redistributive measures to reduce inequality and poverty and whether an inclusive green channel can also contribute to economic growth.

Critical policy questions involving the proactive integration of informal operators are unresolved. Both management plans under consideration call for integrating and supporting them, and areas of agreement exist between the two management plans: (1) incentivize informal collectors to sell upstream by offering prices higher than if they only sold valuable fractions; (2) establish cooperatives among informals; (3) establish dedicated transporters and vehicles for both the long and the short haul of e-waste to buy-back centres/cooperative collection points; and (4) set up an e-waste call centre to provide information facilitating new enterprise development and to offer public service information about e-waste. However, a key difference is whether the integration of the informal sector is facilitated by the government (SAWEEDA, 2018) or via a nonprofit company that is responsible for and/or contracts a private sector provider (ERA, 2018). In the former, the government supports the integration of the informal sector through the establishment of SMEs and through training conducted by universities and technical colleges (SAWEEDA 2018: 40-42). In the latter, the new ERA entity is the facilitator of informal integration and provides training and equipment support to entities from the informal economy with fixed addresses and proper accreditations (ERA, 2018: 32-36). 
A multipronged approach seems preferable, but important decisions will have to be made as to who will regulate informal operators: government, a nonprofit entity, municipalities, the informal operators themselves, or various domains in combination. Smit and Musango (2015a: 9) made valuable suggestions regarding support mechanisms for connecting a green formal economy and a green informal economy (e.g., skills transfers, infrastructure support, incubation support, partnerships in value chain development, employment of best practices, and assurance that informal suppliers adhere to decent work criteria). The approach to engage informal firms may depended on whether these entities are viewed from discourse of resilience and innovation or from a diverging perspective of suvivalism and nuisance and/or from vectors of value to formal economy or value to society (Millington \& Lawhon, 2018). An approach that would address all of these matters is not being discussed.

There are lessons from other developing countries in facilitating a green channel for informal economy operators in waste (Lines et al., 2016). Lines et al. (2016) underscore that the best functioning systems are those embracing an open strategy by including both informal recycling and existing formal value chain enterprises. Hybrid recycling e-waste models in India and China have built upon the public benefits of informal activities, retained and enhanced livelihoods, and reduced major negative aspects of the informal economy by enhancing environmental protection and health standards (Lines et al., 2016). A supportive rather than a direct competition approach has shown to be more beneficial as formal firms cannot operate a collection system as efficiently and affordably, and it also lessens possible sabotage of new formal collection and sorting arrangements (Godfrey et al., 2016). However, the process of making informal operators both legible and official and of creating a hybrid ewaste management system will require informals to be incentivized to undertake lengthy, necessary consultations (no work entails a loss of revenue for pickers; Godfrey et al., 2016).

Several policy initiatives can help shape a more inclusive green channel. Identity cards and a jacket and uniform with a "green force" insignia was a constructive step in a Bengaluru (India) pilot that improved security, proof of legal activities, protection against harassment and bribe-seeking behavior; facilitated business development; and enhanced respect of green entrepreneurs by improving recognition and elevated personal pride in work. In India and the Philippines, waste collectors and dismantlers established a cooperative agency that provided aggregation and auction services whose success led to them securing access to finance and credit as well as profit-sharing to the extent that they were competitive with formal firms (Lines et al., 2016). Collectors' deepening alliances with NGOs can also improve their bargaining power when approaching government, companies, and households for waste, and NGO collaboration and mentorship can facilitate access to small grants for capacity building, training, and collection equipment purchase (Lines et al, 2016). Lessons from China also indicate that policy supports are needed for the informal sector to improve recycling rates, working conditions, and efficiency of informal players (Chi et al., 2011).

Manual processing can also be advanced to improve recycling rates. Chi et al. (2011) note that shredding technology, while efficient, cannot separate some of the components of electronic products, and it produces recyclates of varying quality. Hand sorting by humans is probably still most efficient for the separation of components, and well-trained and managed human sorters produce better recyclates for optimal material recovery. Low-cost improvements can be implemented, such as upgrading apparatus (e.g., density separation tables for shredded cables, shredders for copper-plated boards, and sorting machinery for plastics and copper mixtures (Chi et al., 2011), and allocating assigned handling and storage space thereby improving safety and working environments and upgrading outputs. Such 
initiatives may go some way towards improving operating spaces so pressure is lessened to dispose of/or sell e-waste quickly fearing risks of it been stolen or operations being halted due to illegality so that more green market mechanisms can function. Fixed establishments will also go some way in announcing that lower order activities are also integral components of green e-waste infrastructure.

\section{Conclusions}

Cape Town has an emerging e-waste economy, linking many under-the-radar informals with formal firms that perform most of the aggregation and processing. Disorganization, personal and business ties, lack of visibility, and weak management are features of Western Cape Province's e-waste space economy. The drive to implement a formal management system, collect data, improve the knowledge base, build capacity, harness green tech, and promote South Africa's role in global and regional e-waste value chains is a new transition pathway but a key question is whether it can evolve into a more transformational development intervention premised on social dialogue, inclusion and upliftment of the poor.

Greening e-waste requires a long-term, patient, and well-supported (in terms of finance, scientific knowledge, and internal/external encouragement and the development of green skills (core jobs and jobs with sustainability-orientated changes in workplaces and communities) strategy and full collaboration among stakeholders (e.g., government, scientific community, chemical manufactures, e-product designers, e-waste industry organizations, NGOs retailers, formal e-recycler firms, an array of informal actors [collectors, dismantlers and recyclers, scrap dealers, and part-time workers], and consumers). For a green channel to work connections between the green economy and the informal economy will have to be improved, enabled and better supported (Smit and Musango, 2015a; 2015b). Perhaps, a persuasive case can be made that greening e-waste will have localized environmental benefits and broader socio-economic transformational advances. In South Africa, broad lines of agreement have coalesced about incorporating the informal sector and promoting its participation as respectable and recognized members of the e-waste management landscape. As a senior Westgro official put it, "all stakeholders realize that the green e-waste economy has to be a black economy also" (i.e., positively incorporate poor black informal workers; Interview, June 2018).

Formal management of e-waste will reconfigure chain dynamics, and the various management plans favor the development of technological solutions for upgrading at the processing stage but fail to acknowledge that there will likely be mixed outcomes in applying technological solutions that will include some informals but exclude others. It is far from clear how many and which informals will be incorporated (or excluded from the new systems). Assuming the sector could access all e-waste in Western Cape, potentially 1,5001,800 new jobs (assuming 35-50 jobs per 1,000 tons of e-waste) would be created (GreenCape, 2018: 40).

No doubt, green employment, better work opportunities, improved measurable standards (e.g., wages and conditions) and human and civil rights (freedom of nondiscrimination and increased bargaining power via cooperatives) are highly desirable. Low-skilled casual workers and unorganized workers, however, face exclusion pressures. The heterogeneity among informal firms is not adequately addressed: different policy supports and training programs will be required for different informal firms. The literature points to mixed 
successes of business training programs in the informal economy (Benjamin, et al., 2014) but also highlights useful initiatives: awareness-raising programs related to all aspects of e-waste; a sound spatial distribution of recycling facilities to avoid sites becoming too dense or too scattered; ample storage space and optimal layouts of new facilities; and establishment of information platforms to foster better communication and familiarity among all stakeholders. Moreover, the e-waste management system also needs to give more consideration to secondhand electronics and appliances and to establish standards via a certification system. Developing Atlantis so that it can operate as a green-tech park where SMEs and larger formal firms can co-locate is a new development for Africa, and similar efforts have already proven to be highly successful in several Chinese cities, for example, Zhangzhou (Chi et al., 2011).

Richard Grant, Department of Geography, University of Miami, and School of Tourism and Hospitality, University of Johannesburg, South Africa (rgrant@miami.edu)

\section{References}

Advanced Tropical Environment (ATE) (2012) Identification of the magnitude of electrical and electronic waste (e-waste) situation in South Africa: A strategic approach to international chemical management (SAICM) of e-waste as an emerging policy issue. Africa Institute for Environmentally Sound Management of Hazardous and Other Wastes. Report. Pretoria, DEA.

Africa Institute (2013) WEEE pilot in the SADC region. Research report. Pretoria, DEA.

African Union Commission \& Symantec (2016) Cybercrime \& cyber security: Trends in Africa. Research report. Available at:

https://www.thehaguesecuritydelta.com/media/com_hsd/report/135/document/Cyber-security-trendsreport-Africa-en.pdf (accessed 2 July 2018).

Amankwaa, E. (2013) Livelihoods in risk: Exploring health and environmental implications of e-waste recycling as a livelihood strategy in Ghana. The Journal of Modern African Studies, 51(4), pp. 551-575. DOI: $10.1017 / \mathrm{S} 0022278 \mathrm{X} 1300058 \mathrm{X}$

Anahide, B. (2007) The green w-waste channel: Model for a reuse and recycling system of electronic waste in South Africa. Mater's thesis. Lausanne, Université de Lausanne.

Baldé, C., Wang, F., Kuehr, R. \& Huisman, J. (2015) Global e-waste monitor 2014. Policy report. Bonn, UNU/ITU.

Baldé, C., Forti, V., Gray, V. \& Stegmann, P. (2017) Global e-waste monitor 2017. Policy report. Bonn, UNU/ITU.

Benjamin, N., Beegle, K., Recanatini, F. \& Santini, M. (2014) Informal economy and the World Bank. Policy Research Working Paper 6888. Washington, DC, World Bank.

Borel-Saldin, J. \& Turok, I. (2013) The impact of the green economy on jobs in South Africa. South African Journal of Science, 109(9-10), pp. 1-4. DOI: 10.1590/sajs.2013/a0033

Borland, R. (2018) African digital robots. Available at: http://ralphborland.net/africanrobots (accessed 3 Sept. 2018).

Chi, X., Streicher-Porte, M., Wang, M. \& Reuter, M. (2011) Informal electronic waste management: A sector review with special focus on China. Waste Management, 31(4), pp. 731-742. DOI: 10.1016/j.wasman.2010.11.006

Daum, K., Stoler, J. \& Grant, R. (2017) Towards a more sustainable trajectory of e-waste policy: A review of a decade of research in Accra, Ghana. International Journal of Environmental Research \& Public Health, 14(2), pp. 135-155. DOI: 10.3390/ijerph14020135

Deloitte (2016) Game of phones: Deloitte's mobile consumer survey. The Africa cut 2015/16. Available at: https://www2.deloitte.com/content/dam/Deloitte/za/Documents/technology-mediatelecommunications/ZA_Deloitte-Mobile-consumer-survey-Africa-300816.pdf (accessed 8 June 2018).

Department of Environmental Affairs (DEA) (2012) National waste information baseline report. Pretoria, DEA. Available at: http://sawic.environment.gov.za/documents/1880.pdf (accessed 21 Jan. 2019).

Department of Planning, Monitoring \& Evaluation (2017) Operation Phakisa: Chemicals and waste economy. Policy report. Available at: http://www.operationphakisa.gov.za/operations/Chemical/Pages/default.aspx (accessed 19 June 2018). 
Department of Science \& Technology (DST) (2013) South African waste sector-2012: An analysis of the formal private and public waste sector in South Africa. In: A National Waste RDI Roadmap for South Africa: Phase 1 Status Quo Assessment. Pretoria, Department of Science and Technology. Policy report. Available at: http://wasteroadmap.co.za/download/waste_sector_survey_2012.pdf (accessed 7 June 2018).

Department of Trade \& Industry (DTI) (2017) Economic sectors, infrastructure and employment cluster. Policy report. Pretoria, DTI.

Design Indaba (2018) 6 designers who use waste as inspiration for new products. Available at: http://www.designindaba.com/articles/creative-work/6-designers-who-use-waste-inspiration-newproducts (accessed 2 July 2018).

Dittke, M. (2005) A review of South African environmental and general legislation governing e-waste. Report. Johannesburg, eWASA.

eWASA (2013) Business opportunities in South Africa's e-waste sector. Durban.

E-waste Association of South Africa (eWASA) \& IT Association of South Africa Producer Environmental Group (ITA PEG) (2014) South Africa e-waste industry management plan. Draft Document. Available at: https://ita.org.za/download/south-africa-e-waste-industry-waste-management-plan/ (accessed 6 June 2018).

E-waste Recycling Authority (ERA) (2018) South African e-waste industry waste management plan (v. 1), 2018-2013. Cape Town.

Finlay, A. \& Liechti, D. (2008) E-waste assessment of South Africa. eWASA policy report. Available at: http://www.ngopulse.org/sites/default/files/e-Waste\%20Assessment\%20South\%20Africa.pdf (accessed 7 June 2018).

FtWonline (2017) Green light for Western Cape green tech sector SEZ. Available at: http:/www.ftwonline.co.za/article/124543/Green-light-for-Western-Cape-green-tech-sector-SEZ (accessed 14 May 2018).

Godfrey, L., Muswema, A., Strydom, W., Mamafa, T. \& Mapako, M. (2017) Co-operatives as a development mechanism to support job creation and sustainable waste management in South Africa. Sustainability Science, 12(5), pp. 799-812. DOI: 10.1080/0376835X.2010.508595

Godfrey, L. \& Oelofse, S. (2017) Historical review of waste management and recycling in South Africa. Resources, 6(57), pp. 1-11. DOI: 10.3390/resources6040057

Godfrey, L., Strydom, W. \& Phukubye, R. (2016) Integrating the informal sector into the South African waste and recycling economy in the context of extended producer responsibility. Report. Pretoria, CSIR.

Govender, K. (2016) The management of electronic waste: A case study of Umbogintwini industrial park and Southgate business park in KwaZulu-Natal, South Africa. Master's thesis. Durban, Durban Institute of Technology.

Grant, R. (2006) Working it out? Labour geographies of the poor in Soweto, South Africa. Development Southern Africa, 27(4), pp. 595-612. DOI: 10.1080/0376835X.2010.508595

Grant, R. \& Oteng-Ababio, M. (2013) Mapping the invisible and real "African" economy: Urban e-waste circuity in Accra, Ghana. Urban Geography, 33(1), pp. 1-21. DOI: 10.2747/0272-3638.33.1.1

Grant, R. \& Oteng-Ababio, M. (2016) The global transformation of materials and the emergence of urban mining in Accra, Ghana. Africa Today, 62(4), pp. 2-20. DOI: 10.2979/africatoday.62.4.01

Grant, R. \& Oteng-Ababio, M. (2019) "Electronic waste circuitry and value in Accra, Ghana: Paths not taken for upgrading and deepening of the value chain" In: Schlovin, S., Turok, I., \& Black, A. (eds.) Advances in African Economic and Political Development. New York, Springer.

Grant, R. (2015) Africa: Geographies of change. New York, Oxford University Press.

GreenCape (2016) Waste: Market intelligence report. Available at: http://greencape.co.za/assets/Green-CapeWaste-MIR-2016.pdf_(accessed 12 Sept. 2018).

GreenCape (2018). Waste: Market intelligence report. Available at: https://www.greencape.co.za/assets/Uploads/GreenCape-Waste-MIR-FINAL-WEB-24-5-2018.pdf (accessed 13 June 2018).

Jones, C. (2008) Johnny Clegg exposes SA's e-waste. Available at: https://www.itweb.co.za/content/wbrpOMgz5p57DLZn (accessed 16 June 2018).

Khan, S. (2016) Limits of formalization and horizons of urban citizenship: Insights on law and informality through the lens of electronic waste. Doctoral thesis. Montreal, McGill University.

Lambrechts, D. \& Hector, M. (2016) Environmental organized crime: The dirty business of hazardous waste disposal and limited state capacity in Africa. South African Journal of Political Studies, 43(2), pp. 251268. DOI: $10.1080 / 02589346.2016 .1201727$ 
Lawhon, M. (2012) Relational power in the governance of a South African e-waste transition. Environment and Planning A, 44(4), pp. 954-971. DOI: 10.1068/a44354

Lawhon, M. (2013) Dumping ground or country in transition? Discourses on e-waste transition. Environment and Planning C: Policy and Government, 31(4), pp. 700-715. DOI: 10.1068/c1254

Lines, K., Garside, B., Sinha, S. \& Fedorenko, I. (2016) Clean and inclusive? Recycling e-waste in China and India. Policy report. IED issue paper. Available at: http://pubs.iied.org/16611IIED/?a=I+Fedorenko (accessed 16 July 2018).

Ledwaba, P. \& Sosibo, N. (2017) Cathode ray tube recycling in South Africa. Recycling, 2(4), pp. 2-18. DOI: $10.3390 /$ recycling2010004

Lydall, M., Nyanjowa, J. \& James, Y. (2017) Mapping South Africa's waste electrical and electronic equipment (WEEE) dismantling, pre-processing and processing technology landscape. Mintek External Report \#74. Pretoria, DST. Policy Report. Available at:

https://www.wasteroadmap.co.za/download/weee_technology_landscape_assessment_report.pdf (accessed 8 June 2018).

Machete, F. (2017) Environmental health risks associated with e-waste exposure in Badplaas, Carolina and Elukwatini landfills, Republic of South Africa. African Journal of Science, Technology, Innovation and Development, 9(6), pp. 679-684. DOI: 10.1080/20421338.2017.1355602

Millington, N. \& Lawhon, M. (2018) Geographies of waste: conceptual vectors from the global South. Progress in Human Geography, 42(6), pp 1-20. DOI: 10.1177/0309132518799911

Mohamed, N. (ed.) (2019) Sustainability transitions in South Africa. London, Routledge.

Mouton, A. \& Wichers, B. (2016) A proposed model for South Africa to effectively recycle and dispose of waste electrical and electronic equipment. SAII27 Proceedings. Available at: http://docplayer.net/60685738-Aproposed-model-for-south-africa-to-effectively-recycle-and-dispose-waste-electrical-and-electronicequipment-a-j-j-mouton-1-j-h.html (accessed 19 Jan. 2019).

Nnorom, I. \& Osibinjo, O. (2008) Electronic waste (e-waste): Material flows and management practice in Nigeria. Waste Management, 28(8), pp. 1472-1479. DOI: 10.1016/j.wasman.2007.06.012

Oelofse, S. \& Godfrey, L. (2008) Defining waste in South Africa: Moving beyond the age of 'waste.' South African Journal of Science, 104(7-8), pp. 242-246.

Osibinjo, O. \& Nnorom, I. (2007) The challenge of electronic waste (e-waste) in developing countries. Waste Management \& Research, 25(6), pp. 489-501. DOI: 10.1177/0734242X07082028

Rogerson, C. (2006) 'Second economy’ versus informal economy: A South African affair. Geoforum, 38(6), pp. 1053-1057. DOI: 10.1016/j.geoforum.2007.01.005

Schenck, R., Blaauw, D. \& Viljoen, K. (2016) Enabling factors for the existence of waste pickers: A systematic overview. Social Work, 52(1), pp. 35-53.

Schluep, M., Dittke, S., Newson, G., Kane, C. \& Hieronymi, K. (2008) A material recovery facility in Cape Town, South Africa, as a replicable concept for sustainable e-waste management and recycling in developing countries. Available at:

http://citeseerx.ist.psu.edu/viewdoc/download?doi=10.1.1.626.2012\&rep=rep1\&type=pdf $($ accessed 16 July 2018).

Smit, S. \& Musango, J. (2015a) Exploring the connections between the green economy and the informal economy in South Africa. South African Journal of Science, 111(11-12), pp. 1-12.

Smit, S. \& Musango, J. (2015b) Towards connecting the green economy with the informal economy in South Africa: A review and way forward. Ecological Economics, 116(August), pp. 154-159. DOI: 10.1016/j.ecolecon.2015.04.022

Snyman, J., Vorster, K. \& Jacobs, S. (2016) Towards sustainable e-waste management in South Africa. Conference Presentation $5^{\text {th }}$ Annual Conference on Sustainable Waste Management, June 21-24. Athens, Greece. Typescript.

South African Waste Electrical and Electronic Enterprise Development Association (SAWEEDA) (2018) Industry Ewaste management plan for South Africa 2019-2024. Durban.

Sullivan, H. (2014) Trash or treasure: Global trade and accumulation of e-waste in Lagos, Nigeria. Africa Today, 61(1), pp. 89-112. DOI: 10.2979/africatoday.61.1.89

Swilling, M., Musango, J. \& Wakeford, J. (2016) Greening the South African economy. Scoping the issues, challenges and opportunities. Cape Town, UCT Press.

Tshimbana, T. (2014) An evaluation of electronic waste management in Ba-Phalaborwa local municipality, Limpopo Province, South Africa. Doctoral thesis. Pretoria, University of South Africa. 
Western Cape Government (2013) Green is smart: Western Cape green economy strategy framework. Cape Town.

Widmer, R. \& Lombard, R. (2005) E-waste assessment in South Africa: A case study of Gauteng province. St. Gallen, Swiss Global E-Waste Management Programme. 